Recanati, F. 2002. Unarticulated constituents. Linguistics and Philosophy 25: 299-345. Recanati, F. 2004. Literal Meaning. Cambridge: Cambridge University Press.

Stanley, J. and Z. Szabo. 2000. On quantifier domain restriction. Mind and Language 15: 219-61.

\title{
A solution for Russellians to a puzzle about belief
}

\section{SEAN CRAWford}

1. According to Russellians, there is one proposition expressed (in a context) by the two sentences 'George Eliot is a novelist' and 'Mary Ann Evans is a novelist', given that George Eliot is Mary Ann Evans (Salmon 1986; Braun 1998). It has, as its constituents, the woman George Eliot and the property of being a novelist, and can be represented as an ordered pair:

$<$ George Eliot, being a novelist $>$.

Since belief is a binary relation holding between a believer and a proposition (ignoring time and tense), there is likewise one proposition expressed (in a context) by the two sentences 'Ralph believes George Eliot is a novelist' and 'Ralph believes Mary Ann Evans is a novelist'. It too can be represented as an ordered pair:

$<<$ Ralph, $<$ George Eliot, being a novelist $>>$, believes $>$,

though, when it comes to focusing on the content of Ralph's belief, which is the present topic, it is perhaps more perspicuous to represent it as

Believes (Ralph, <George Eliot, being a novelist $>$ ).

On this view, the two sentences:

(1) Ralph believes George Eliot is a novelist

(2) Ralph believes Mary Ann Evans is a novelist

cannot diverge in truth value, since they express the same proposition. The problem for the Russellian (or the 'Millian') is that a puzzle of David Kaplan's (1968-69: $\$ 11)$ seems to show that they can diverge in truthvalue and that therefore, since the Russellian holds that (1) and (2) express the same proposition, the Russellian view is contradictory.

Imagine that Ralph has read Middlemarch and The Mill on the Floss by one 'George Eliot' but is too benighted to realize that the author is 
female and is using a male pen name. Imagine further that he is familiar with the details of the early life of a young woman called 'Mary Ann Evans', in particular of her struggles with Christianity say, but that he has no idea that she grows up to become Eliot the novelist. Ralph is certain that Eliot is a novelist; he is not sure about Evans, however, and though he wonders whether she may be a novelist (too, as it were), he decides that, given the evidence he has, he simply does not know and requires more information to arrive at a firm opinion on the matter. So it seems that Ralph has suspended judgement about whether Evans is a novelist. In order to suspend judgement about whether Evans is a novelist, clearly Ralph must not believe that Evans is a novelist. So if Ralph has indeed suspended judgement, it appears that we have here a case where (1) is true and (2) is false - a situation inconsistent with Russellianism. (2), of course, is just one half of the doxastic component of Ralph's apparent suspension of judgement, since to suspend judgement with respect to something is (at least) neither to believe nor disbelieve that thing; but the lack of belief, as opposed to the lack of disbelief, is the relevant half, since it causes the contradiction, and so I shall concentrate primarily on it throughout.

Gareth Evans frames the argument this way. With only the resources of the Russellian conception, we cannot, he claims, 'consistently describe the belief system' of Ralph in this situation (1985: 317). For on that conception, 'there is a single proposition or thought content $-[<$ George Eliot, the property of being a novelist>] - to which the subject both has and fails to have the relation corresponding to the notion of belief'. Evans goes on to say that 'Not only does this fail to give any intelligible characterization of the subject's state of mind; it appears to be actually contradictory' (1982: 84). It seems, in other words, that the Russellian must represent the situation thus:

(3) Believes (Ralph, <George Eliot, being a novelist $>$ )

(4) $\sim$ Believes (Ralph, <Mary Ann Evans, being a novelist $>$ ),

which clearly is contradictory (given that George Eliot is Mary Ann Evans). A couple of points should be noted here. First, it is not essential to the puzzle that the beliefs involved be singular ones. The puzzle can be generated equally with beliefs about a general kind that goes by two different names - beliefs about courgette/zucchini, for example - or even, as Nathan Salmon has pointed out (1998: 109), a general kind that has one name but two different pronunciations, such as tomato. A solution to the puzzle is not, then, it seems, to be found in any doctrine concerning singular reference, but in more general considerations. Second, it is important to emphasize that I am concerned solely with the argument that (1) and (2) can diverge in truth-value because of the possibility of the kind of alleged suspension of belief just described; there are other potential 
routes to the claim that (1) and (2) can diverge in truth-value but they cannot be taken up here.

2. When confronted with Kaplan's puzzle, the tendency has been for Russellians steadfastly to maintain the foregoing 'coarse-grained' or 'Russellian' conception of propositions and pursue a strategy of 'analysing' the binary belief relation as the existential generalization of a ternary relation - called ' $B E L$ ' by Salmon and others - among a person, a Russellian proposition and a 'proposition guise' or 'way of believing' this Russellian proposition. Applied to the case at hand, this gives us, in Salmon's (1986) notation,

$\exists x[$ Ralph grasps that Eliot/Evans is a novelist by means of $x \&$ $B E L($ Ralph, that Eliot/Evans is a novelist, $x)]$

and

$\exists x[$ Ralph grasps that Eliot/Evans is a novelist by means of $x \&$ $\sim B E L$ (Ralph, that Eliot/Evans is a novelist, $x)]$,

which are compatible, because each existential claim is made true by distinct values of $x$. These values are the 'proposition guises' that are functions of, respectively, Ralph and the sentence 'George Eliot is a novelist', on the one hand, and Ralph and the sentence 'Mary Ann Evans is a novelist,' on the other (Salmon 1986: 117). This resolution of the puzzle consists in answering Yes to the pressing question: Does Ralph believe Eliot/Evans is a novelist or not? The answer is that, Yes, strictly speaking, Ralph does indeed believe Eliot/Evans to be a novelist. This follows directly from the ternary analysis of belief: since Ralph stands in BEL to the singular proposition that Evans/Eliot is a novelist and some 'way of believing' it, he thereby believes that singular proposition. It is, therefore, strictly speaking incorrect to say that (2) is false (Salmon 1986: 112). (1) and (2) express the same proposition and Ralph does indeed believe that proposition. The relevant half of Ralph's seeming suspension of belief with respect to whether Evans is a novelist is captured by the ternary analysis of what Salmon calls 'withholding belief' (the second of the two preceding existential generalizations) - which, crucially, does not entail failing to believe. Following Kaplan's (1968-69) influential analysis of belief de re, Salmon points out that 'the analysis in terms of $B E L$ uncovers that there is yet a third position in which the negation sign may occur' (112), which is precisely what was lacking in (4) and which seemed to force the Russellian to put the negation sign in front of the whole attribution thus creating the contradiction with (3).

3. I agree with Salmon that Ralph believes Eliot/Evans is a novelist, that (1) and (2) cannot diverge in truth-value, and that it is thus incorrect to 
say that (2) is false. But I do not think that we need to resort to the somewhat peculiar notion of 'withholding belief without failing to believe', as analysed by Salmon in terms of BEL and 'proposition guises', to account for what is going on with Ralph, cognitively speaking; neither do I think that, quite generally, a ternary analysis of belief is required to create the extra place for the negation sign. The good old commonsense notion of binary belief is capable of handling the situation all on its own.

To see this, consider what suspension of belief appears to involve. It is one thing to believe (or disbelieve) something; it is quite another thing to suspend belief about that thing. The suspension of belief, or the reservation of judgement, has a degree of cognitive sophistication beyond mere believing, in that it arguably involves the ability to have beliefs about what one does not believe. This is because a deliberative process that aims to establish whether or not $p$, must terminate, as long as it is not interrupted, in the formation of some judgement or belief about the matter in question, about whether $p$. When the deliberative process terminates in a reservation of judgement with respect to $p$, the belief consequently formed about the matter is the belief that one does not know whether or not $p$. Suspension of judgement necessarily involves thoughts about one's own epistemic perspective on whether or not $p$, namely, that one's epistemic perspective falls short of establishing whether $p$ and thus that one does not know whether $p$. Now, obviously, in this kind of case, to believe that one does not know $p$ is not merely to think that one does not have enough evidence strictly speaking to claim to know $p$ but that for all that one still believes $p$. Rather, in this kind of case, to believe that one does not know whether $p$ is to believe that one neither believes $p$ nor disbelieves $p$ - 'I don't know' is simply more colloquial and concise than the philosopher's long-winded 'I neither believe nor disbelieve'. This is why in all the examples of the puzzle in which the protagonist's inner soliloquy or verbal utterance is described, he inevitably makes reference to himself and his lack of beliefs (or knowledge). For example, Salmon's character, who appears to be suspending belief about whether a certain criminal is dangerous, thinks to himself, 'I used to believe that he is a dangerous man, but now I'm not so sure ... I don't know what to think' (1986: 94). The same is true of Schiffer's character, whose verbal utterance is: 'I neither belief nor disbelieve...' (1992: 509). The content of these expressions of belief, whether they are covert mental acts or overt linguistic acts of communication, essentially involves the person himself and his supposed lack of possession of certain beliefs. Reference to oneself and one's lack of beliefs is not merely a natural but optional way of describing what is going on; it is an essential feature of what it is to suspend judgement. In order to suspend judgement about whether $p$, it is, I am suggesting, necessary to believe that you do not believe or disbelieve $p$. So for Ralph to come 
to suspend judgement about whether Mary Ann Evans is a novelist, he must at least come to believe that he does not believe Evans is a novelist. This is not only a belief about Evans; it is also a belief about Ralph himself and his lack of a certain belief. This belief of Ralph's is easily represented by the Russellian:

(5) Believes (Ralph, $<<$ Ralph, $<$ Eliot/Evans, being a novelist $>>$, does not believe>).

I suggest that (4) is false and should be replaced by (5). To suspend judgement about whether $p$ cannot, of course, only be a matter of believing that you neither believe nor disbelieve $p$; obviously, you must also actually neither believe nor disbelieve $p$. Normally, believing that one does not believe (or disbelieve) $p$ is sufficient for one not to believe (or disbelieve) $p$. But Ralph's case is unusual in that it is not true that he does not believe Eliot/Evans is a novelist, even though he believes that he does not believe this. For (3) is true:

(3) Believes (Ralph, <George Eliot, being a novelist $>$ ).

The important point is that since (5) is consistent with (3), and their conjunction gives an adequate description of Ralph's state of mind, the Russellian is not trapped in any contradiction. In (5), the binary relation of believing is stuck into the ordered pair that represents the content of Ralph's belief, and this opens up another place into which to insert the essential negation sign. This, it will be recalled, is just what is needed to represent the situation in a way that avoids the contradiction with (3). (5) shows, then, that there is no need for the Russellian to 'go ternary' and invoke 'proposition guises' or 'ways of believing' in order to capture the conclusion of Ralph's deliberations about whether Mary Ann Evans is a novelist.

What is going on, then, psychologically speaking, is that Ralph is, at least in part, thinking about himself and his own thoughts. He believes that he does not believe that Eliot/Evans is a novelist - but, of course, he does believe this, for (3) is true. So Ralph has not in fact suspended judgement; he only thinks he has. Ralph believes he does not believe something he in fact believes. Is there something unacceptably counterintuitive about this? Can a person have beliefs that he actively and genuinely denies having? Can a person think he is suspending judgement when he is not? He can indeed if the Russellian conception of belief is correct. For according to that conception, the identity and difference of the contents of our thoughts are not necessarily transparent to us in the sense of being open to introspective examination and comparison (cf. Millikan 1993). The contents of our thoughts are determined by the causally and historically contingent relations we bear to things in the 
contexts in which we find ourselves and the nature of these relations and contexts is often not completely known by us at any one time. Since I can fail to keep track of the objects of my beliefs, owing to their movements through space and time and changes in appearance, or, what comes to the same thing, my own movements into and out of different contexts, it can happen that I believe I do not have a certain belief about something when in fact I do have that belief about that thing. Ralph has lost track of George Eliot: he has failed to trace her career as the young woman struggling with Christianity to the later author of various famous novels. It is this that is responsible for his thinking he is suspending judgement about whether a certain woman is a novelist when he is not. If he had not lost track of her, then his belief that he does not believe her to be a novelist would in all likelihood be correct. But as soon as he loses track of her, the possibility arises that his beliefs about what he does not believe may be incorrect.

In closing, let me note that the Russellian's rejection of the principle that if a person denies he believes $p$ then he does not believe $p$, goes handin-hand with the Russellian's better-known rejection of the principle that rational subjects cannot believe contradictions. Both principles stand and fall together. For suppose that Ralph believes George Eliot is a novelist and believes that Mary Ann Evans is not a novelist. According to the Russellian, both of the following would then be true:

(3) Believes (Ralph, <George Eliot, being a novelist $>$ )

(6) Believes (Ralph, <Mary Ann Evans, not being a novelist $>$ ),

and Ralph would have rationally held contradictory beliefs. According to Russellians (Salmon 1986; Braun 1998) and others (Millikan 1993), there is nothing philosophically objectionable about this. If this is so, then since Ralph believes George Eliot is a novelist, arguably he also believes that he does not believe George Eliot is not a novelist; at any rate, he can easily come to believe this. The Russellian will represent this belief as:

(7) Believes (Ralph, $<<$ Ralph, $<$ George Eliot, not being a novelist $>>$, does not believe $>$ ).

If (3) and (6) can both be true simultaneously then there is nothing stopping (3), (6) and (7) from all being true simultaneously. But (6) and (7) can be true at the same time only if the principle that if a person believes he does not believe $p$, then he does not believe $p$, is false.

The Open University Milton Keynes MK7 6AA, UK m.s.crawford@open.ac.uk 


\section{References}

Braun, D. 1998. Understanding belief reports. Philosophical Review 107: 555-95.

Evans, G. 1982. The Varieties of Reference, ed. J. McDowell. Oxford: Clarendon Press.

Evans, G. 1985. Understanding demonstratives. In his Collected Papers. Oxford: Clarendon Press.

Kaplan, D. 1968-69. Quantifying in. Synthese 19: 178-214.

Millikan, R. 1993. White queen psychology. In her White Queen Psychology and Other Essays for Alice, 279-363. Cambridge, MA: MIT Press.

Salmon, N. 1986. Frege's Puzzle. Cambridge, MA: MIT Press.

Salmon, N. 1998. Is de re belief reducible to de dicto? Canadian Journal of Philosophy Suppl. Vol. 23: 85-110.

Schiffer, S. 1992. Belief ascription. Journal of Philosophy 89: 499-521.

\section{'That'-clauses as existential quantifiers}

\section{FrançOIS ReCANATI}

1. The following assumptions jointly constitute the standard view regarding the logical form of belief reports:

(1) 'believe' and other propositional attitude verbs denote relations between an agent and a truth-bearing entity (a 'proposition');

(2) 'that'-clauses are referential expressions which denote propositions.

On this view 'John believes that grass is green' has the form $a R b$. The name 'John' and the 'that'-clause 'that grass is green' are both referential expressions, whose respective denotata fill the two argument-places in the relation denoted by the verb. In this way we can account for the validity of inferences such as

John believes that grass is green,

Sam doubts whatever John believes,

Therefore, Sam doubts that grass is green.

This is formalized as

BELIEVES (John, that_grass_is_green)

$\forall x$ (BELIEVES (John, $x) \rightarrow$ DOUBTS (Sam, $x)$ )

DOUBTS (Sam, that_grass_is_green) 